\title{
Is There a School to Terror Pipeline? The Case of France
}

\author{
Cheryl Lynn Duckworth \\ Nova Southeastern University \\ cheryl.duckworth@nova.edu
}

\begin{abstract}
In the wake of the January 2015 attacks on Charlie Hebdo (a satirical newspaper in Paris), there was much commentary on free speech, security, intelligence and the marginalization and dispossession of some young Muslim immigrants (and children of immigrants). Analysis has seemed, reasonably, to focus on economic opportunities, as well as addressing some identity and cultural issues, such as whether or not female Muslims should be allowed to wear a headscarf. The media reported that the two young men who seem to have led the attack on Charlie Hebdo had dropped out from school, going on to work low-wage jobs such as pizza delivery. Little of the news coverage details their education beyond that they were remembered as average Parisian boys, as media coverage focused of course on live breaking events, with less in-depth analysis of the social, economic and political factors driving the broader conflict between European and North American states and their Muslim immigrant residents and citizens. The Charlie Hebdo attacks, like 9/11, were only one expression of this broader escalating and expanding conflict. The academic literature does discuss in depth the history of France's colonization of countries such as Algeria and Morocco, as well as the racist oppression and economic marginalization Maghrebi immigrant families face - even two generations later (Bienkowski, 2010; Bowen, 2007; Cesari, 2002; Franz, 2007; Limage, 2010; Keaton, 2005; Jugé \& Perez, 2006; Landorf \& Pagan, 2005; Levine, 2004; Mahmood, 2006; Zimmerman, 2015). This paper will thus explore the question of whether there is a "school to terror" pipeline - that is, is there anything about the pedagogy, curriculum, school culture or educational policies of France which might well be contributing to the radicalization of young people? I will conclude with consideration of what peace pedagogy might be able to contribute in terms of conflict transformation.
\end{abstract}




\section{Who Were the Kouachi Brothers?}

Beyond observing that the Kouachi brothers had dropped out of school, and had been engaged in typical student activities such as soccer (and apparently marijuana), scant attention seems paid to the details of their educational experience. We have a skeleton sketch and little more. The attacks were quite recent, and the public narratives shaped about these sorts of attacks tend to be shallow and surface. We do know they attended a boarding school, and then were transferred to a foster center when their mother became ill and died (their father had already passed at this point). One source seems to suggest that she committed suicide (Lichfield, 2015) though other media outlets do not specify this. The brothers seem to have been reasonably successful in school, depending on the source one reads - raising the question of course of what in particular led to the drop out. The confusion becomes even deeper when one notices that media profiles, for example the New York Times (NYT) and The Guardian, contradict one another on biographical facts such as if the brothers were abandoned or the fate of their parents is unclear (Chrisafis, 2015) or if they did in fact die (as the NYT asserts) (Callimachi and Yardley, 2015). Media profiles also seem to contradict somewhat on the question I am most interested in as regards to how successful the boys were in their schooling, though this ought to be knowable from school records. The Independent describes the orphanage school they attended after their mother's death as quite violent, to the point where the teachers were afraid of them (Lichfield, 2015). Mistrust, alienation and violent conflict between "Franco-French" and Muslim French students run deep in modern French history, as elsewhere in Europe and North America. New outlets documented the riots of 2007 and 2014 extensively. Prior to the Charlie Hebdo attacks, two other attacks on Jewish institutions occurred in 2012, and both of the attackers in these two cases were originally in juvenile court (Chrisafis, 2015). This detail of course is of interest to an investigation of a possible "school to terror pipeline". Connecting these dots suggests to me that the daily lived experience of these young people in school warrants more attention. (Note that a limitation of this discussion is the author's lack of French language skills.)

Countering violent extremist (CVE) theorists often speak of "push/pull" factors relating to radicalization. Push factors might include lack of economic opportunity, for example; pull factors refer to the need for belonging or active recruitment by extremist groups (Lombardi et al., 2014). Contact with a radical cleric in prison, as well as persistent unemployment, seems to have constituted such factors, but I argue that a better understanding of their education would also assist in countering violence extremism. One further detail from a New York Times profile was significant: the preacher who seems to have radicalized the Kouachi brothers, Farid Benyettou, had a sister who was expelled from school for wearing her hijab (Callimachi \& Yardley, 2015). Indeed, such state suppression of minority identities, be it language, clothing, faith or other traditions, appear to be the surest means of guaranteeing violent conflict. From the skeleton profiles we have of the Kouachi brothers, one can see these push/pull factors evident.

In the U.S., youth advocates and peace educators often speak of a "school to prison pipeline" as a means of articulating the discriminatory school discipline, among other educational injustices, that young black men and women in particular face. This too often results in rates of suspension, expulsion or other disciplinary action for young black boys and girls at much higher rates than other school children. This school discipline of young black boys and girls is often more likely to involve formal law enforcement, as Alexander (2012) notes in her recent work The New Jim

Journal of Contemporary Issues in Education, 2016, 11(1), pp. 86-96 
Crow. Such a dynamic can trap youth on a conveyer belt from the juvenile justice system to the adult system. With stark similarities to the oppression of African Americans in the U.S., the vast majority of France's prison population is made up of Maghrebis (whether they themselves are immigrants or not). A Brookings study recently provided statistics from a quantification by two French scholars. The study's authors concluded,

We are faced with a justice system that concentrates its energies on youth of foreign origin. Youth of immigrant origin may also lose some faith in the justice system given that it does not always protect them from crime in equal measure either. Prosecution of racist acts against citizens of North African origin, for example, has been rare (see figure 1-9). Although hundreds of incidents were reported, just seven cases were brought to court in 1999, twelve in 2001, and twenty-nine in 2002 (Laurence \& Vaisse, 2007, p. 42).

Such a reality can hardly help but result in rage-yet scholarship and policy analysis continues at least linguistically to position the youth as the problem rather than a racist justice system.

As a peace educator reflecting on the events in Paris (and the wider conflict of which that event was only one expression), I am therefore inspired to wonder if there is a "school to terror pipeline". Strikingly only $40 \%$ of French immigrant children proceed to university (Kramer, 2004). It goes without saying that no teacher, school or curriculum is responsible for the crimes Chérif and Saïd Kouachi and their accomplices committed. Yet we must ask about the role of their schooling in their radicalization as it may well constitute a push factor in terms of CVE theory: What were their classrooms like? Did their schools reach out to include them? Did teachers have the skill and autonomy they needed to meet the needs of such students? Were students allowed to express their identity or told not to? Was their own history or identity taught at all, was it recognized and respected? This article will address these questions, building on the current body of research that investigates education and extremism (Davies, 2008; Duckworth, 2014) as well as youth and radicalization (e.g. Venhaus, 2010).

Much like racial minorities in the U.S., the experience of immigrant and Maghrebi students in France appears oppressive, a system of structural violence. One scholar observes, "Even among second-generation French North Africans, secondary school and university graduation rates lag behind those of the 'Franco-French'..." (Fellag, 2014). Fellag goes on to note that a number of reasons have been suggested for this, such as lack of federal funding and an educational policy of tracking students by ostensible ability, which results in racial and economic minority students being placed in the lowest tracks. This tracking system, common in the U.S. as well as France, is especially counterproductive since the vocational tracks are much less likely to entail in-depth civic, political or service learning components and furthermore are likely to open only limited career opportunities (Fellag, 2014; Janmaat \& Mons, 2011). These can reasonably be seen as push factors in the language of CVE theory (Lombardi et al., 2014).

\section{Contemporary and Historical Context}

The unique political culture and history of France is relevant here, of course. While there is no space for a full treatment of that here, a few observations are of use. The scholarly literature on schooling in France seems to concur that the French interpretation of the role of schooling Journal of Contemporary Issues in Education, 2016, 11(1), pp. 86-96 
emphasizes the promotion of loyalty to the state, and utter blindness to ethnicity and neutrality when it comes to promotion of cultural or civil values (Limage, 2010). This has been the case so strongly, in fact that it has been difficult for French government offices to collect data on the welfare of various demographic groups, or the impact on various ethnic or cultural groups of particular state systems and policies. The belief seems to have been that this in and of itself would create division and fall afoul of equal treatment of all citizens. The historical fear was (and is) that any approach other than this strict supposed neutrality would compromise the students' educational experience by subjecting him or her to possible different treatment from that of other students. This ultimately has its origins in the republican values emerging out of the French Revolution and at least, according to Limage (2010), few teachers even today question it.

To the contrary, in reality students are not the same, in France or elsewhere. They come to their education with different skills, needs, cultures and histories. Much like the limitations of racial colorblindness in the U.S., which ultimately serves to obscure continuing racial injustices; the discourse of neutrality I argue, is itself problematic (see Duckworth, 2014). First, there is no neutral. Embedded within any cultural or political narrative is a set of specific values that have evolved over generations out of particular historical experiences. The staunch secularism of France, many scholars note, emerged from the need to reign in the corrupt power of the Catholic Church in the $18^{\text {th }}$ century (Bowen, 2007; Calhoun, 2011). Unless this false notion of neutrality is contested, however, the specificity or underlying cultural assumptions of a particular political narrative might never be visible, thus appearing neutral and promoted by culturally embedded and biased state institutions. Of course, Muslim girls and their families have provided precisely that contestation; insisting that the very stance itself of (ostensible) neutrality change and positing that one can be both a loyal, republican French citizen and expressive of one's private cultural, ethnic and religious heritage.

This perhaps helps explain why studies of immigration in both the U.S. and Europe have often noted that U.S. immigrants seem much better assimilated than in Europe broadly (e.g., Levine, 2004). Levine suggests that, despite this, France historically has been reasonably successful in integrating its Algerian and other immigrants from the Maghreb, especially when that immigration was smaller scale and more individual as opposed to a more challenging mass immigration. Yet as large waves of immigrants continued, and the children and grandchildren of post-WWII immigrants, especially from France's former colonial territories emerged, challenges increased. As Levine writes, in Paris especially,

for young Muslims, rejected by the job market and the majority culture and plunged into the crime-and drugs atmosphere that has become pervasive for at least the younger residents of the banlieues, reversion has been to Islamic culture, including some aspects that violate modern French (and indeed, other Western) mores, and sometimes to religious fundamentalism (p. 15).

The most visible and by far the most contentious expression of this, of course, has been the refusal of the French state to allow young Muslim women to wear their traditional Islamic headscarf at school, convinced that the desire to do so is the result of pressure from men (especially fathers and husbands). French Muslims, who argue that the famed French secularism is not as complete as the state may claim, have some evidence on their side; Catholic, Protestant

Journal of Contemporary Issues in Education, 2016, 11(1), pp. 86-96 
and Jewish schools do receive some state financing (Limage, 2010, p. 26), and critics note that in practice, Catholic students are not commonly challenged for wearing a cross to school.

Schools are perhaps the most important socio-political space, outside of the family, where national and political identity is shaped and learned. This is even more the case when we focus on national identity where of course a nation's history and citizenship, the content of their particular imagined community, are explicitly and implicitly taught. Hence discrepancies between how students are treated cannot help but have a marginalizing and radicalizing impact, especially in a world of $21^{\text {st }}$ century social media when grievances can so easily be shared and narratives both shaped and contested. Interestingly, it seems that Catholic schools have stepped into the gap as the legal proceedings and protests continue against traditional French secularism, allowing Muslim girls to wear the hijab (e.g., Bennhold, 2008; Chrisafis, 2013). The psychological damage caused by the interaction of Muslim families with French public schools has been documented by journalists. One mother who was denied the opportunity to help chaperone her young son's school field trip, described her trauma and humiliation: "Children are not stupid. They understand. A lot of children who have been exposed to this treatment of their mothers have had psychological difficulties. My son would have fits of rage, he was selfharming and hitting his head against the wall at home because I couldn't go" (Chrisafis, 2013, para 6).

One scholar describes the role of marginalization of North African Muslim immigrants (or those of such descent whose parents or grandparents immigrated) in France as a result of discrimination, sometimes de jure, sometimes de facto, in French state institutions — schools included:

"Some of these newly religious young adults are finding in Islam a credible alternative to marginalized lives, resulting from unemployment, drugs, alcohol, and delinquency. Others, who question the value of progress and modernity - especially among the educated and successful - are discovering a sense of belonging they cannot achieve within a society whose schools, political parties, trade unions, and professions have failed to provide a collective sense of common good" (Cesari in Haddad, 2002, p. 42).

Of the many arguments advanced to support banning the hijab in French public schools, one of the most common is that the wearing of the hijab offends French republican values by subordinating women to men. Ironically though as Shachar notes, this has been counterproductive if one's aim is indeed to support and empower French Muslim women. She writes,

Significantly, instead of encouraging the inclusion of French Muslim women in both their religious community and their secularist state, the new anti-hijab law makes the attainment of education-the only long term strategy that has consistently been linked to improved life chances and empowerment for girls and women worldwide-more difficult than ever. Rather than facilitating their inclusion in multiple cultural and legal worlds of tradition and secularism, the hijab ban makes movement across cultural barriers much harder, if not virtually impossible" (Shachar in Bienkowski, 2010, p. 452).

Clearly authentic self-expression and autonomy for French Muslim women would achieve more 
freedom for these citizens on whose behalf the state claims to act.

Identity of course is not static, and as generations settle, new forms of social organization, issues and narratives emerge. Over the past several generations, this appears to have occurred in France, as immigrant families settled, assimilated, refused to assimilate and formed communities based on a common migrant experience of discrimination. In their new context, this was more salient than the particularities of being Moroccan, Tunisian or Algerian specifically. Cesari (2002) for example notes, "Despite the fact that their founders shared North African origins, these organizations emphasized the social constraints that resulted from exclusion, rather than ethnic origins and culture" (p. 9). This French Maghrebi identity formation process, as Cesari describes it, especially for the children or grandchildren of immigrants who feel French, has centered on grievance and exclusion resulting from the discriminatory experience with the French state and culture, manifesting in a much more politicized Islam in France than before. This new identity is more centered on the experience of the French state than in the particulars of being Tunisian, Moroccan or Algerian. Again, this narrative and political philosophy is in direct opposition to the official French approach, which defines equality as sameness, especially in the sense of all students being treated the same and given the same knowledge (Limage, 2010).

The literature on the role of and integration of especially North African Muslims conveys this theme consistently: the practice of Islam in France has become almost inevitably politicized due to the French policies such as the hijab ban in schools, or the restrictions on building Islamic schools or mosques, presumably based on the fear that allowing such schools and mosques would lead to a more assertive, even radical, Islam. Ironically, being more forthcoming with such licenses for Islamic schools I think would be deradicalizing; it is in the public schools that students appear to be experiencing the kinds of isolation and humiliation that can radicalize. While there is not space to detail this in full, of course the occupation of Algeria in particular, and French involvement in the Algerian civil war, is also relevant in both native-French and Maghrebi French historical memory. While France has taken some measures to better address integration, as in other countries of Europe or in North America, successes seem isolated at best. One important trend working against radicalization, on which French public schools must work to build, is the development of French Muslim civic life-for example, the League of Muslim Women, Muslim youth groups and outreach services, and various councils of Islamic leaders and clerics (Fellag, 2014), though certain of these organizations are critiqued more as co-option and another tool for state assimilation than a tool to develop the equality of French Muslim citizens. It is also important to note that, despite efforts at integration, radical leaders do continue to engage in explicit recruitment of especially young men in the poorest, immigrant neighborhoods of Paris and other cities, and particularly in France's prisons.

Also of importance is the segregation of students (intentionally or not) within schools, a problem hardly unique to France. For one example, one journalist described two seemingly sister schools, one populated with mainly North African immigrant students which focuses on vocational education and has a reputation for violence. (Recently someone threw a Molotov cocktail into the administrative offices.) The other school offers the standard curriculum needed for real economic integration and advancement yet this school is populated by primarily non-immigrant students. Worryingly, the students are prevented from mixing, one presumes out of a fear that 
conflict or violence may ensue (Kramer, 2012). What could be a teachable moment is missed due to fear.

I was reminded here of an experience I had as an educator using my American literature class to address racial conflict in the local community. I had invited a nationally recognized guest speaker, an African American professor of American literature who specialized in Mark Twain, to address the use of racial slurs in Huckleberry Finn. This was such an exciting opportunity for our students that my departmental colleagues asked to be included, and the students themselves showed more engagement in this activity than I had seen all year. A white administrator refused to allow the program to go forward on the grounds that a group of African American parentactivists, whom she clearly felt ill-equipped to communicate with, would be offended. "Why create the problem when we do not currently have any issues?" the administrator's argument went. Yet clearly the dialogue was not creating the problem, but instead acknowledging and addressing a problem that already existed. Schools empowered to build cultures of peace would be loath to let such opportunities pass by. I draw this parallel between the school Kramer describes above and my own experience as a public school English teacher in suburban Virginia to illustrate two pedagogical points. First, the current industrial-era model of schooling is not adequate to provide the social, intercultural, global citizenship and problem solving skills students in the $21^{\text {st }}$ century will need. Intercultural communication will certainly be one of those skills. Second, teacher and educational leadership training must focus much more on community engagement and dialogue skills to support educational leaders in meeting the demands of schools where violence and ethnic and class conflict are a reality. Perhaps if this administrator had received some formal training or had access to expertise on intercultural dialogue to empower her, she might have made a different choice.

\section{Policies and Pedagogies for a More Inclusive Vision}

The experience of French immigrants and French Maghrebis has received much scholarly attention, but this literature has focused much more on history, public policy, culture and economic integration. Less extensive attention has been given to elaborating and articulating the experience of North African French students and developing curriculum and pedagogy that might foster building a culture of peace. Given the recent media focus, I am using the case study of France here, but these reflections could apply in any number of countries. Pursuing the following policies, I believe, can help interrupt what I am calling the "school to terror" pipeline.

\section{Decentralize (to some extent)}

While some measure of curriculum coherence and a set of unified standards may be needed, policy mandates have a poor track record of success from the federal level. A blanket ban on the hijab, much like zero-tolerance policies in the U.S., may be well intended but remove the ability of those who know the students best to judge the local context and reality. They are best equipped to ascertain if a student is indeed on the path to radicalization, or if he or she is simply choosing to express an Islamic cultural identity. If the ban cannot be overturned, which is the best solution, at a minimum its implementation must be flexible. This recommendation is supported by much conflict resolution and peace education theory (e.g., Bajaj, 2015). To be clear, however, my position is that it must be overturned. 


\section{Desegregate}

It may hardly need stating that the inequalities faced by Maghrebi students must be addressed at the policy level. This applies especially to the curricular and funding inequalities that are so typical of educational and other systems with respect to minority communities, such as the tracking of Maghrebi students into vocational schools which promise an uncertain economic future at best. Yet one hesitates to blithely set this as a policy recommendation as though the trouble was a mere bureaucratic oversight. Such is not the case. The structural inequalities reflect political discrimination, deep historical fears and social divisions. Courageous and determined leadership will be needed, from educational leaders as well as politicians. Yet schools, in seeking to build a culture of peace within their own walls and within their local communities, arguably need not wait for federal policies to improve in order to adapt curriculum, implement intercultural dialogues, teach students about unconscious bias and stereotypes and highlight for students contested historical narratives underlying the current conflict. Empirically this is supported by the Janmaat and Mons study (2011) which analyzed quantitative data from a number of countries (France included) and found that a less-tracked model was associated with more tolerant attitudes towards immigrants. They write, "policy makers concerned about pockets of alienation and intolerance... ought to prolong the period of common schooling with undifferentiated classes" (p. 77). This is also consistent with a peace and social justice pedagogy. Dialogues and experiential curriculum designed to foster peace building skills, empathy and intercultural problem solving are central to peace pedagogy (Bajaj, 2015; Duckworth, 2014).

\section{Hybridity as an Educational Outcome: The Need for Narrative Transformation}

Above I briefly mentioned the importance of inviting students to share in shaping the national civic narrative. Here I posit that the citizenship narratives themselves in countries such as France (and one could say, the U.S.) can be seen as "push" factors in terms of CVE theory. They are exclusive and carry the assumption that to be an American, or French, is to be white (Duckworth, 2014). Granted, these narratives are contested by some white French and Americans, but they are dominant, historically entrenched and deeply embedded within how citizenship is implicitly and explicitly understood - and therefor how it is taught and experienced in public schools. This must be interrupted and replaced with a more hybrid and cosmopolitan national narrative.

Lynn Davies' (2008) work on educating against extremism focused on just such a vision of hybridity - mulitvocality and a variety of historical narratives and epistemologies that can be considered valid. Applying her thinking here, I argue that this sort of hybridity ought to be articulated as an educational outcome. Some programs, such as the International Baccalaureate, do this but it is far less common in public schools. Schools can host student dialogues, even opening them to the local community. These dialogues can focus on what students believe to be the source of the conflict; they can then collaborate with adults in developing solutions and envisioning a more secure and peaceful future.

Venhaus (2010) in his study of why youth join Al-Qaeda, noted the primacy of a need for identity, belonging and esteem to explain the vulnerability of youth to extremist ideologies. The above curriculum and pedagogical suggestions fit with the recommendations that emerged from his study; he divided his respondents into four basic categories: identity seekers, revenge seekers, status seekers and thrill seekers. For identity and status seekers in particular, the opportunity to contribute and to be affirmed and heard is not to be underestimated. The right kind of school 
dialogues, leadership opportunities and service learning can feasibly meet such basic human needs.

My review of the literature on integration of Maghrebi students in France suggests that the students are too often considered to be a problem, rather than the solution. Unfortunately this is a common theme in curricula and educational reform. The crisis facing France must not be wasted, as the proverb goes. To build cultures of peace in schools, administrators and teachers can host student focus groups and integrate oral histories into the classroom. Experiential curriculum such as supporting interfaith dialogues or other kinds of service learning can be developed. Students can be invited to write and speak on the hijab ban, and compare the approach of France to other countries that have been experiencing similar strife. The key principle to apply is that North African French students must be repositioned in a new narrative that understands them as a solution, not the problem. As ever, this is not to suggest that schools alone can resolve the conflict between France's Muslims and the "Franco French"; yet neither can schools, their pedagogy, policies nor practices be overlooked as is too often the case outside of educational circles. This preliminary investigation of a possible "school to terror pipeline" in France I hope concludes then with pragmatic recommendations, some larger and longer-term but some smaller scale and which can be implemented with minimal resources such that schools can begin to lead in building a culture of peace to catalyze conflict transformation. 


\section{References}

Alexander, M. (2012). The New Jim Crow: Mass incarceration in the age of colorblindness. NYC: New Press.

Bajaj, M. (2015). 'Pedagogies of resistance' and critical peace education praxis, Journal of Peace Education, 12 (2), 154-166. http://dx.doi.org/10.1080/17400201.2014.991914

Bennhold, K. (2008, September 29). French Muslims find haven in Catholic schools. New York Times. Retrieved from http://www.nytimes.com/2008/09/30/world/europe/30schools.html?pagewanted=all\&_r=0

Bienkowski, S. (2010, Spring). Has France taken assimilation too far? Rutgers Journal of Law and Religion, 11, Part 2, 437-458.

Bowen, J. R. (2007). Why the French don't like headscarves. Princeton, NJ: Princeton University Press.

Calhoun, C. (2011). Secularism, citizenship, and the public sphere. In C. Calhoun, M.

Juergensmeyer, \& J. Van Antwerpen (Eds.). Rethinking secularism (pp. 75-91). New York, NY: Oxford University Press.

Callimachi, R., \& Yardley, J. (2015, January 17). From amateur to ruthless Jihadist in France. Chérif and Saïd Kouachi's path to Paris attack at Charlie Hebdo. Retrieved from http://www.nytimes.com/2015/01/18/world/europe/paris-terrorism-brothers-said-cherif-kouachicharlie-hebdo.html

Cesari, J. (2002). Islam in France: The shaping of a religious minority. In Y. Haddad-Yazbek (Ed.). Muslims in the West, from sojourners to citizens (pp. 36-51). Oxford, UK: Oxford University Press.

Chrisafis, A. (2013, July 22). France's headscarf war: 'It's an attack on freedom'. The Guardian. Retrieved from http:/www.theguardian.com/world/2013/jul/22/frances-headscarf-war-attack-onfreedom.

Chrisafis, A. (2015, January 12). Charlie Hebdo attackers: Born, raised and radicalized in Paris. Retrieved from http://www.theguardian.com/world/2015/jan/12/-sp-charlie-hebdo-attackerskids-france-radicalised-paris

Davies, L. (2008). Educating against extremism. Stoke on Trent, UK: Trentham Books.

Duckworth, C. L. (2014). 9/11 and collective memory in US classrooms: Teaching about terror. NYC: Routledge.

Franz, B. (2007, Winter). Europe's Muslim youth: An inquiry into the politics of discrimination, relative deprivation and identity formation. Mediterranean Quarterly. 18(1), 89-112. http://dx.doi.org/10.1215/10474552-2006-036

Fellag, N. (2014). The Muslim label: How French North Africans have become "Muslims" and not citizens. Journal on Ethnopolitics and Minority Issues in Europe, 31(4), 1-15.

Janmaat, J. G., \& Mons, N. (2011). Promoting ethnic tolerance and patriotism: The role of education system characteristics. Comparative Education Review, 55(1), 56-81. http://dx.doi.org/10.1086/657105

Jugé, T. S., \& Perez, M. P. (2006). The modern colonial politics of citizenship and whiteness in France. Social Identities, 12(2), 187-212. http://dx.doi.org/10.1080/13504630600583387

Keaton, T. (2005). Arrogant assimilation: National identity politics and African-origin Muslim girls in the other France. Anthropology and Education Quarterly, (36)4, 405-423. http://dx.doi.org/10.1525/aeq.2005.36.4.405

Keaton, T. (2006). Muslim Girls and the other France: race, identity, and social exclusion. Journal of Contemporary Issues in Education, 2016, 11(1), pp. 86-96 
Bloomington, IN: Indiana University Press.

Kramer, J. (2004, November 22). Taking the veil: How France's public schools became the battle ground in a culture war. The New Yorker. Available from http://www.newyorker.com/magazine/2004/11/22/taking-the-veil

Landorf, H., \& Pagan, L. (2005). Unveiling the hijab. The Social Studies, 96, 171-176.

Levine, R. A. (2004, July). Assimilating immigrants: Why America can and France cannot. RAND Europe. Retrieved from http://www.rand.org/pubs/occasional_papers/OP132.html.

Laurence, J., \& Vaisse, J. (2007). Integrating Islam: Political and religious challenges in contemporary France. Brookings Institution Press. Retrieved from http://www.brookings.edu/press/books/chapter_1/integratingislam.pdf

Lichfield, J. (2015, January 18). Paris attacks: Why the Charlie Hebdo gunmen Saïd and Chérif Kouachi made an unlikely terror cell. The Independent. Retrieved from http://www.independent.co.uk/news/world/europe/paris-attacks-why-the-charlie-hebdo-gunmensad-and-chrif-kouachi-made-an-unlikely-terror-cell-9986391.html Limage, L. J. (2010). Education and Muslim identity: The case of France. Comparative Education, 36(1), 73-94. http://dx.doi.org/10.1080/03050060027773.

Lombardi, M., et al. (Eds). (2014). Countering violent extremism among youth to prevent terrorism. Amsterdam, NL: IOS Press.

Mahmood, S. (2006). Secularism, hermeneutics, and empire: The politics of Islamic reformation. Public Culture. 18(2), 323-347. http://dx.doi.org/10.1215/08992363-2006-006

Venhaus, J. (2010, May). Why youth join Al Qaeda: Special report. United States Institute of Peace. Special Report 236. Retrieved from http://www.usip.org/sites/default/files/SR236Venhaus.pdf

Zimmerman, D. D. (2015). Religiosity as an identity: Young Arab Muslim women in the United States and France. Journal of Religion \& Spirituality in Social Work: Social Thought, (34)1, 51-71. http://dx.doi.org/10.1080/15426432.2014.937023. 